MARKO PRŠIĆ, Ph.D.

E-mail: mprsic@grad.hr

DALIBOR CAREVIĆ, Ph.D.

E-mail: car@grad.hr

University of Zagreb, Faculty of Civil Engineering

Kačićeva 26, HR-10000 Zagreb, Croatia

DAVOR BRČIć, Ph.D.

E-mail: davor.brcic@fpz.hr

University of Zagreb,

Faculty of Transport and Traffic Sciences

Vukelićeva 4, HR-10000 Zagreb, Croatia
Traffic Infrastructure

Review

Accepted: Sep. 27, 2010

Approved: Mar. 8, 2011

\title{
DETERMINING INLAND WATERWAY PARAMETERS WITH APPLICATION TO THE SAVA RIVER
}

\begin{abstract}
The article provides a definition of inland waterway parameters with the emphasis on the international waterway classes IV, $V_{a}$ and $V_{b}$ relevant to the Sava River. The parameters have been defined through the comparative analysis based on international classification of inland waterways, the available theoretical assumptions, and available and published physical model researches. The channel parameter problems have not been considered herein.

The philosophy of the applicable UN/ECE classification of 1992 consists in defining the relevant waterway structures and navigable water levels only. The waterway parameters are then determined in compliance therewith for each individual waterway based on the navigable channel morphology, through the morphological, technical and economic analysis. Through such an iterative procedure, a detailed standardization of the Sava River waterway parameters was created for the international classes IV, Va and Vb, serving as basis for the current analysis of the Sava River navigability for the purpose of gaining informative concept of the scope of water works to be executed and the financial dimension of requested works for short-term and long-term periods.
\end{abstract}

\section{KEY WORDS}

inland waterway, the Sava River, waterway class, standardization, river bed morphology

\section{INTRODUCTION}

The primary objective of this article is to conduct an analysis of the Sava River waterway on the basis of the international treaty, the international classification of inland waterways and the theoretical assumptions. The analysis in the first part of the article thus exclusively deals with the waterway parameters for the natural rivers. Since the Republic of Croatia is a signatory of the AGN [1] Agreement, only the international navigable waterway parameters of classes IV, Va and $\mathrm{Vb}$ related to the navigable Sava River have been considered herein. Croatia declared, namely, the Sava River within the AGN Agreement as a waterway of class IV (minimum international class for the existing waterways). The Danube-Sava multipurpose canal was declared to be the waterway of class Vb. However, in the far future, there is an option of raising the waterway class to $\mathrm{Va}$ or $\mathrm{Vb}$ (minimum international class for a new waterway on rivers and channels).

Based on the analysis of the Sava River morphology, below is the estimate of the technical interventions needed to meet the requirements of the international navigability class of the Sava River, currently IV, and in the future class $\mathrm{Va}$ and $\mathrm{Vb}$. The estimate of financial requirements is also made along with the estimated technical interventions.

\subsection{Relevant vessels, vessel convoy, navigable water level, manoeuvres during navigation and navigation speed}

Relevant vessels and the respective convoys used in this analysis have been defined within the 1992 UN/ECE classification [2]. The international waterway of class IV shall provide navigation to self-propelled ships of the following dimensions: length I = 80-85 m; width $\mathrm{b}=9.5 \mathrm{~m}$, draught $\mathrm{t}=2.5 \mathrm{~m}$, bearing capacity $1000-1500$ [t] as well as to stiff pushing convoys such as lighter of type $\mathrm{E} 1+$ push-boat of dim. Imax $\times \mathrm{b} \times \mathrm{t}$ $=85 \times 9.5 \times 2.5-2.8[\mathrm{~m}]$, deadweight 1000-1500 [t], [1 and 2]. Pushing convoy is relevant. The relevant vessels for the future classes ( $\mathrm{Va}$ or $\mathrm{Vb}$ ) are stiff pushing convoys consisting of a lighter type E2 + push-boat, and $2 \times \mathrm{E} 2+$ push-boat. 
For the navigable water level, the following is adopted:

VPV [cm or $m$ a.s.I.] High navigable water level: water level of 1 to $3 \%$ duration

$\mathrm{V}_{65 \%}$ [cm or $\mathrm{m}$ a.s.I.] Water level of $65 \%$ duration at which all waterway parameters shall be fully met,

NPV [cm or m a.s.I.] Low navigable water level: water level of $95 \%$ duration at which the navigable channel need not be completely met, i.e. the navigable channel depth shall be provided with $60 \%$ of the full depth.

Navigation with great caution, reduced safety and frequently reduced speed represents a manoeuvre. There are four greatly different types of manoeuvre on the waterway: overtaking, passing by, turning and passing under a bridge. For the inland waterway analysis, the relevant manoeuvre is passing by on the river or the channel waterway.

In respect of the navigation speed on natural rivers, the following is adopted:

$\mathrm{v}_{\mathrm{s}}=12 \mathrm{~km} / \mathrm{h}$ for self-propelled ship, speed in still waters or a relative vessel speed;

$\mathrm{v}_{\mathrm{s}}=9 \mathrm{~km} / \mathrm{h}$ for pushing convoy, speed in still waters or a relative vessel speed.

\subsection{Former inland waterway parameter research}

In order to calculate the detailed plan view parameters of the navigable channel in the river bend, the minimum radius of the waterway shall be selected based on the morphological analysis, and then the corresponding navigable channel width shall be calculated. The quantity of training works shall then be specified, and the minimum radius changed, if needed. The minimisation of development costs is generally achieved by the introduction of one-way navigation at certain points because of the state border and zoning problems. The analysis is therefore very complex and interactive. On the other hand, in the 1960 UN/ECE classification [3], in the 1975
Danube Commission Recommendations [4], in the 1999 PIANC analyses [5] regarding class $\mathrm{Vb}$, as well as in the existing radius values within the European waterway network there is information concerning approximate minimum radius values, which may still be accepted in the navigation practice. In case of stiff pushing convoys of the international class IV to VII, the theoretical ratio of the navigation channel width in the bend and its radius is defined by the drift angle $\beta$ for stiff pushing convoys. In theory, experimental parameters have been specified only for class IV. These parameters may also be applied with certain departures to class $V$ because of the similarity of the convoys. On the basis of the above mentioned procedure, the minimum navigation channel radii on the Sava River have been selected herein and waterway parameters in the bend have been determined per classes. Since the natural rivers consist of bends and counter-bends, i.e. there are no long directions, the parameters in the bend are relevant for the entire river section of uniform morphology.

By specifying the above mentioned input parameters, it shall be possible to elaborate the analysis of a minimal navigable channel width on the rivers (in the direction and in the bend), as well as other parameters such as the navigable channel depth.

\subsection{Applied research methods}

Since the waterway parameters have not been specifically defined by the international classification (or standardization), the procedure for the standardization of parameters of the Sava River is hereby proposed on the basis of comparative analysis of the existing recommendations, theoretical assumptions and the available experimental research.

On the basis of standardized waterway parameters and by the analysis of the morphological characteristics of the Sava River, the water works needed to ensure the Sava River to comply with the international waterway standard may be estimated. In addition to the estimate of the necessary water works, the estimate of work costs was also carried out.

Table 1 - Minimal radii of the navigable channel in the bend on the Sava River in comparison with local and international waterways according to the 1960 UN/ECE classification

\begin{tabular}{|c|c|c|c|c|c|}
\hline & & \multicolumn{4}{|c|}{ The minimal radius of navigavle channel in the bend $(\mathrm{m})$} \\
\hline & & \multicolumn{2}{|c|}{ natural rivers } & \multicolumn{2}{|c|}{ canalized rivers } \\
\hline & & UN/ECE 1960. & The Sava Initialive & UN/ECE 1960. & The Sava Initialive \\
\hline \multirow{3}{*}{ International class } & IV & $350-650$ & 360 & $350-650$ & 360 \\
\hline & Va & - & 360 & - & 360 \\
\hline & $\mathrm{Vb}$ & $450-750$ & 450 & $450-750$ & 450 \\
\hline
\end{tabular}




\section{INLAND WATERWAY PARAMETER ANALYSIS}

\subsection{Waterway width in the direction}

The intention is to define the minimum waterway width in the direction for the two-way navigation of the inland waterway of class IV, Va and Vb, which is critical during the low navigable water level. It consists of two parallel navigable tracks: for upstream and downstream navigation of one self-propelled ship or one single-row pushed convoy (Figure 1). (Evidently, during higher water levels, navigation of two-row pushed convoys, parallel towing convoys and self-propelled ship convoys by a barge tied "under the arm" shall be possible).

The navigation in the direction on the meandering river is so rare that it does not exist as a rule. The navigation is from the bend into the counter-bend. Nevertheless, the direction navigation has also been presented as it is of fundamental importance for the following analysis of the navigation in the bend. Considering the track width, the navigation in the bend with the radius exceeding $2,000 \mathrm{~m}$ corresponds to the navigation in the direction. In that case, the drift angle of the vessel or of the stiff convoy in the bend $\beta$ is more or less equal to the wriggle angle of the vessel or of the stiff convoy in the direction $\Delta \beta$, and the tracks are more or less of the same width. During navigation in the direction, it is important that the vessel or the convoy departs, i.e. wriggles in the attempt of keeping the direction. One of the reasons for wriggling is hydrodynamic, i.e. wriggling occurs because of the propeller drifting, the unevenness of the channel and water flow, the unevenness of the vessel and cargo arrangement, and particularly because of the action of the wind pressure force on the superstructure. The second reason for wriggling occurs in the case of asymmetric navigation, passing by or overtaking in the restricted waterway, depending on the layout of the vessels where they become laterally shifted or attracted. Therefore, for safety reasons, it is necessary to define the wriggling angle $\Delta \beta$ (Figure 1). According to Wiegleb [6], the experimental horizontal wriggling angle of the vessel or of the convoy, $\Delta \beta$ varies from $1.5^{\circ}$ to $3^{\circ}$, where:

$\Delta \beta_{1}=1.5^{\circ}$ horizontal wriggling angle of the vessel or of the stiff convoy in case of upstream navigation,

$\Delta \beta_{2}=3^{\circ}$ horizontal wriggling angle of the vessel or of the stiff convoy in case of downstream navigation,

Verification of the experimental wriggling angle $\Delta \beta$ has been made on the basis of an experiment [5] conducted in Munich on the physical river model in the

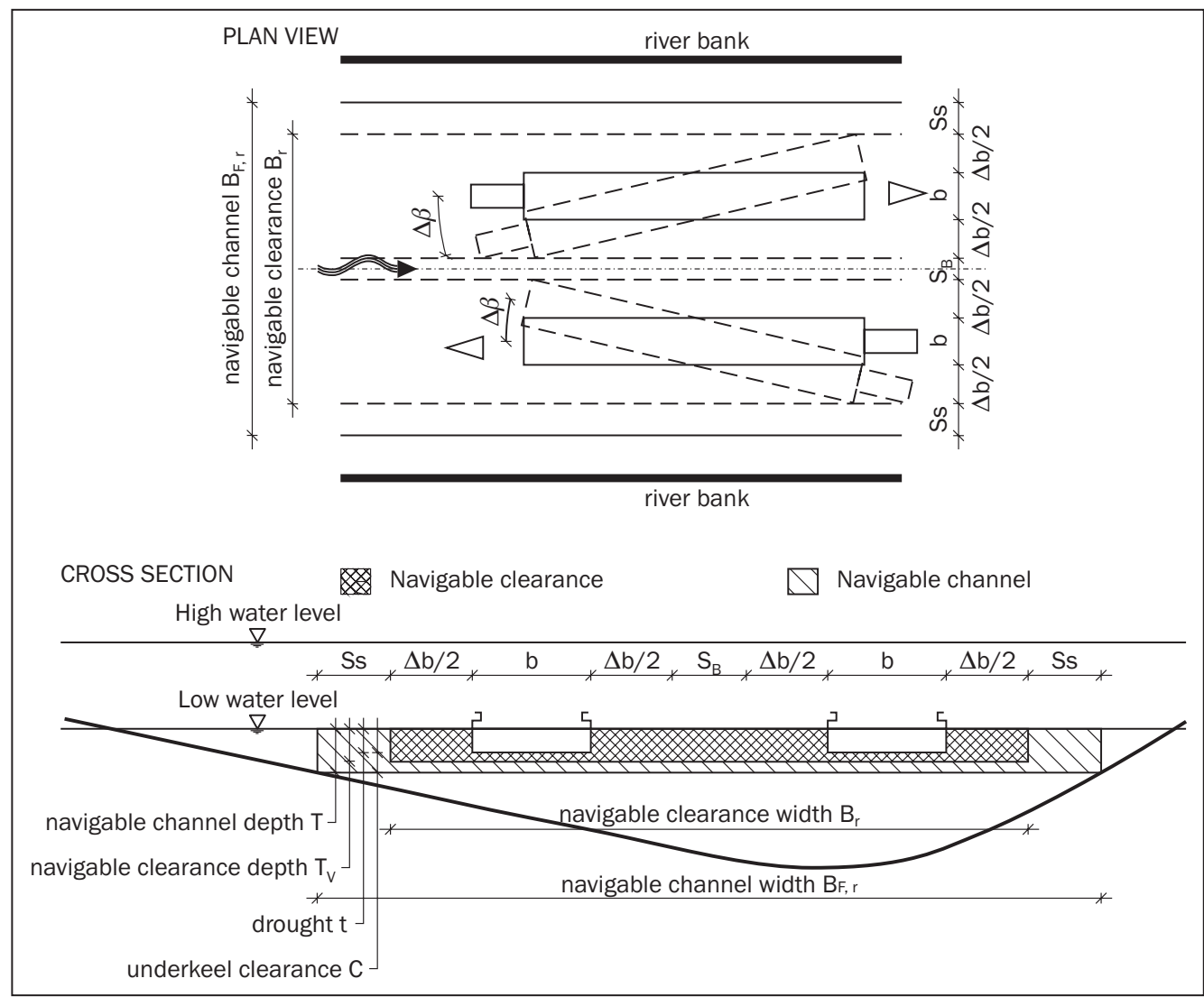

Figure 1 - Definition sketch for the parameters of the navigable clearance and of the navigable channel in natural and trained rivers, the case of passing by 
direction, in 1:25 scale in the nature. The model corresponds to the natural river section $1,300 \mathrm{~m}$ long and $157 \mathrm{~m}$ wide with the "Jochnestein" self-propelled ship (95 m x $11.4 \mathrm{~m}$ ).

Following the example from the experiment [5], for the bank slope 1:3, the self-propelled ship $I_{\max }=95 \mathrm{~m}$, the minimum safety distance between the bank and the ship $a=6-7 \mathrm{~m}$ and the upstream navigation in the direction, the drift angle $\Delta \beta \approx 3^{\circ}$ is derived. For the vertical bank with $a=5 \mathrm{~m}$, $I_{\max }=95 \mathrm{~m}$ and downstream navigation, the drift angle $\Delta \beta \approx 3.5^{\circ}$ is derived. In this way, experimental drift angle during the navigation in the direction was verified as indicated in [6].

The navigable channel widths for the two-way navigation in the direction $\mathrm{B}_{\mathrm{F}, \mathrm{r}}$ have herein been determined analytically, on the basis of the available theoretical and practical methods [6] [7] [8] [9] [10] [11] for all classes of waterways. Accepting the terms as referred to in Figure 1, the following is obtained:

$\mathrm{B}_{\mathrm{F}, \mathrm{r}}[\mathrm{m}]=\mathrm{S}_{\mathrm{s}}+\mathrm{B}_{\mathrm{r}}+\mathrm{S}_{\mathrm{s}}=\mathrm{S}_{\mathrm{S}}+$

$+\left(2 \times b+\mathrm{S}_{\mathrm{B}}+4 \times \Delta \mathrm{b} / 2\right)+\mathrm{S}_{\mathrm{S}}=$

$=3.5 \times b+2 \times \tan 3^{\circ} \times I_{\max }=$

$=3.5 \times b+0.1 \times I_{\max }$

where:

$\mathrm{B}_{\mathrm{r}}[\mathrm{m}]$ - width of a two-way navigable clearance on the river during overtaking in the downstream navigation in the direction,

$\mathrm{B}_{\mathrm{F}, \mathrm{r}}[\mathrm{m}]$ - width of two-way navigable channel in the direction on the navigable river,

$\left.\mathrm{Ss}_{\mathrm{s}} \mathrm{m}\right]$ - horizontal reserve between navigable clearance and river profile,

$\mathrm{S}_{\mathrm{B}}[\mathrm{m}]$ - horizontal reserve between vessels, i.e. convoys.

In this classification $\mathrm{S}_{\mathrm{S}}=\mathrm{S}_{\mathrm{B}}=0.5 \times \mathrm{b}$ has been adopted. The term $\Delta \mathrm{b}=\tan \Delta \beta \times \mathrm{I}_{\max }$ is used, where
$\Delta \beta=3^{\circ}$ in conformity with the above conducted analysis. Relevant general conditions have been applied as follows: passing by is taken as relevant manoeuvre on the rivers.

\subsection{Waterway width in the bend}

The following approach has been applied to all natural and canalized rivers of class IV - VII where the pushing technology is dominant. Specific values are provided for the Sava waterway of class IV, Va, and Vb. The waterway width in the bend $B_{F, r, c}$ in principle depends on the minimal radius $R_{\min }[\mathrm{m}]$ of the waterway bend axis, while in the actual calculation the radius of internal edges $R_{i}[m]$ of each navigable track is used (Figure 2).

Navigable tracks in the bend are much wider than the tracks in the direction. Whereas the vessels in the direction only wriggle with the angle of maximum horizontal rotation of $\Delta \beta= \pm 3^{\circ}$, the vessels in the river bend in the downstream navigation drift with the angle of horizontal rotation of up to $20^{\circ}$. Drifting is less expressed in the upstream navigation because "the rudder obeys better" and therefore the upstream track is narrower. The expression for the twoway navigable channel width in the bend in the case of passing-by manoeuvre $\mathrm{B}_{\mathrm{F}, \mathrm{r}, \mathrm{c}}$ (Figure 2) includes upstream and downstream navigable tracks and reads as follows:

$B_{F, r, c}[m]=S_{S}+B_{r}+S_{S}=S_{S}+\left\{B_{i}+S_{B}+B_{2}\right\}+S_{S}=$ $\left\{B_{1}\right\}+\left\{B_{2}\right\}+1.5 \times b$

$$
\begin{aligned}
& \mathrm{B}_{\mathrm{F}, \mathrm{r}, \mathrm{c}}=\left\{\sqrt{\left(\mathrm{R}_{\mathrm{i}, 1}+\mathrm{b}\right)^{2}+\left[\frac{\mathrm{I}_{\max }}{2}+\left(\mathrm{R}_{\mathrm{i}, 1}+\frac{\mathrm{b}}{2}\right) \operatorname{tg} \beta_{1}\right]^{2}}-\mathrm{R}_{\mathrm{i}, 1}\right\}+ \\
& +\left\{\sqrt{\left(\mathrm{R}_{\mathrm{i}, 2}+\mathrm{b}\right)^{2}+\left[\frac{\mathrm{I}_{\max }}{2}+\left(\mathrm{R}_{\mathrm{i}, 2}+\frac{\mathrm{b}}{2}\right) \operatorname{tg} \beta_{2}\right]^{2}}-\mathrm{R}_{\mathrm{i}, 2}\right\}+1.5 \cdot \mathrm{b}
\end{aligned}
$$

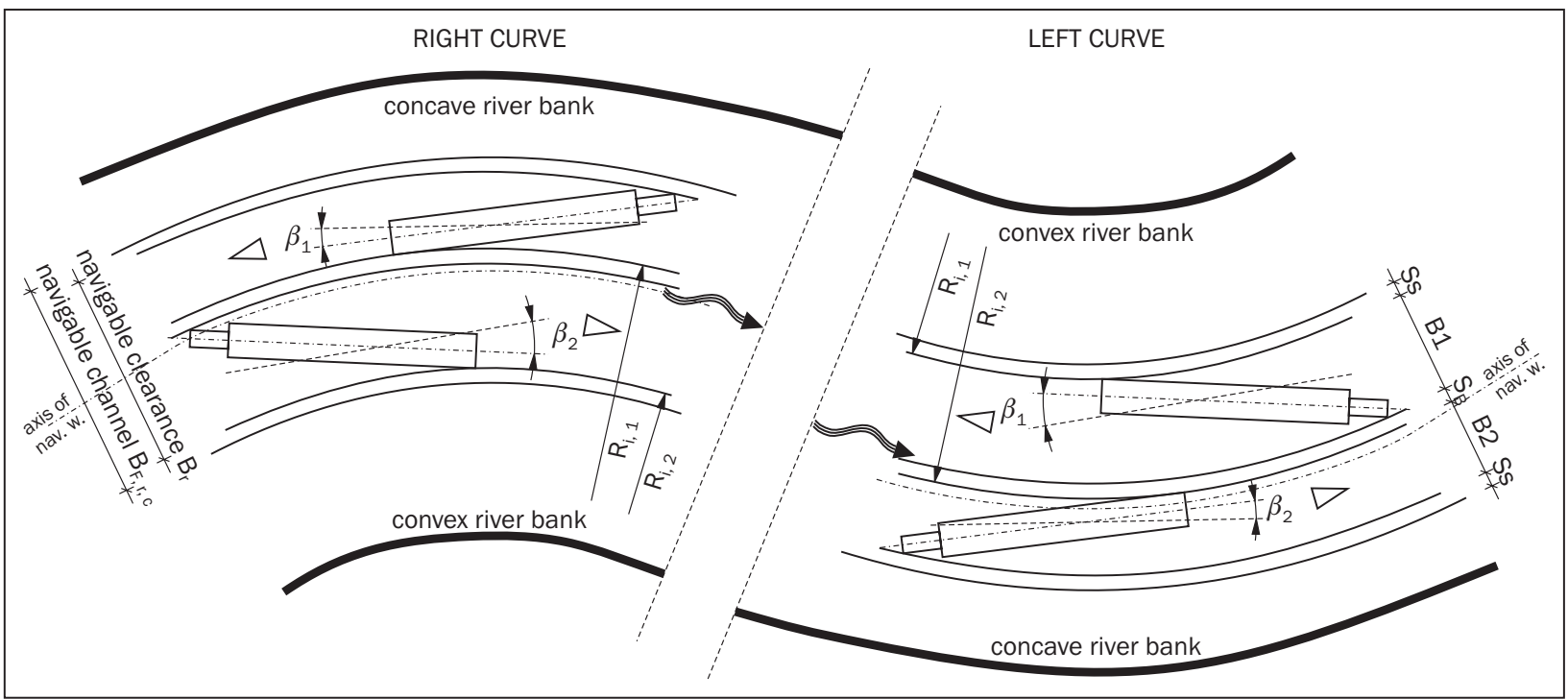

Figure 2 - Definition sketch for the parameters of the navigable clearance and of the navigable channel in natural and trained rivers. The case of passing by in the curve. 
$\mathrm{B}_{\mathrm{F}, \mathrm{r}, \mathrm{C}}[\mathrm{m}]$ - width of a two-way navigable channel on the natural or trained river in the bend in the case of passing by (Figure 2);

$\mathrm{R}_{\mathrm{i}, 1}[\mathrm{~m}]$ and $\mathrm{R}_{\mathrm{i}, 2}[\mathrm{~m}]$ - radius of internal edge (nearer to the curve centre) of navigable track $B_{1}$ in upstream navigation and $\mathrm{B}_{2}$ in downstream navigation on the natural or trained river in the bend (Figure 2);

$\beta_{1}\left[{ }^{\circ}\right]$ and $\beta_{2}\left[^{\circ}\right]$ - horizontal drift angle of the vessel or of the stiff pushing convoy in the bend in upstream and downstream navigation on natural or trained river ( Figure 2).

Other: ditto equation (1).

The procedure of determining the navigable channel width in the bend for any class of waterway by expression (2) is iterative. The analysis of the Sava River class IV, Va and Vb is presented in Figure 3. The following general conditions were relevant in determination: minimal radius for the Sava $360 \mathrm{~m}$, the horizontal drift angles $\beta_{1}$ and $\beta_{2}$ for the calculation of the navigable track width B1 and B2, are interpreted from expression (2) in upstream and downstream river navigation in the bend depending on the $\mathrm{R}_{\mathrm{i}, 1}$ and $\mathrm{R}_{\mathrm{i}, 2}$ radius and on the central angle of the navigable channel bend $\alpha=30\left[^{\circ}\right]$ as indicated in the Graewe's experimental diagram [7]. The central angle $\alpha=30\left[^{\circ}\right]$ was used as for larger central angles, the width of tracks B1 and B2 remains constant [12]. The diagrams have been made for stiff pushing convoys consisting of one or two lighters E1 tied in a series. Other conditions are the same as referred to in Chapter 2.1.

\subsection{Waterway depth}

The needed depth of the navigable channel T both on the channels and on the natural rivers is determined by: vessel draught - $t$, longitudinal vessel trim $\Delta \mathrm{t}$, vessel speed sink $-\mathrm{S}_{z}$, imprecision $-\mathrm{y}$ and absolute reserve - $\Phi[9]$ :

$\mathrm{T}=\mathrm{T}_{\mathrm{v}}+\mathrm{y}+\Phi=\left(\mathrm{t}+\Delta \mathrm{t}+\mathrm{S}_{\mathrm{z}}\right)+\mathrm{y}+\Phi=\mathrm{t}+\mathrm{C}$

where:

$\mathrm{T}_{\mathrm{v}}[\mathrm{m}]$ - navigable clearance depth;

$\mathrm{t}[\mathrm{m}]$ - vessel draught;

$\Delta \mathrm{t}[\mathrm{m}]$ - longitudinal trim of one vessel;

$\mathrm{S}_{z}[\mathrm{~m}]$ - speed sink;

$\mathrm{Y}[\mathrm{m}]$ - imprecision (measurements, excavations or back fill of a river or channel bed crosssection);

$\Phi[\mathrm{m}]$ - absolute reserve;

$\mathrm{C}[\mathrm{m}]$ - underkeel clearance.

The navigable channel depth for international depth classes of the Sava waterway, calculated as referred to in (3), is shown in Figure 4. In this case, the following general conditions were relevant: - for the calculation of the navigable channel depth, region-



Figure 3 - Width of navigable channel in natural and trained rivers. The case of passing by in the curve. $R$-minimal radius.

al waterways (< of class IV) have to provide smaller draught than $2.5[\mathrm{~m}]$, the existing international (class IV) minimum 2.5 [m], and the future international Va and $\mathrm{Vb}$ ) minimum 2.8 [m] [2 and 5]. - The dynamics of navigation in the vertical plane essentially depends on the cross-section restriction of the waterway; therefore, it is similar with natural and canalized rivers, and different with channels. For the determination of the navigable channel depth in two-way navigation, central navigation in the direction and full speed of the vessel or the convoy are relevant. The depth defined in this way is valid for the entire navigation channel width. Longitudinal trim of one vessel adopted from experience is: $\Delta t=0.1[\mathrm{~m}]$. Speed sink values $S_{z}$ of class IV to $\mathrm{Vb}$ of waterway on channels or rivers are interpreted or estimated from the Kuhn's experimental diagrams [8]. Since there are no diagrams for all classes, the most similar existing diagrams were used. Absolute reserve is taken for class IV: $\Delta \mathrm{t}=0.3[\mathrm{~m}]$ and for class $\mathrm{V}: \Delta \mathrm{t}=$ $0.4[\mathrm{~m}]$. The reserve due to imprecision is taken as an arbitrary value: $y=0.3[\mathrm{~m}]$. The waterway depth for the maximum draught should be provided at $V_{65 \%}$ AGN [1]. On smaller natural rivers, which achieve their navigable channel depth for maximum draught at high water levels only, is recommended to reduce, at low navigable water level (which corresponds to the water level of $95 \%$ duration) the navigable channel depth by up to $60 \%$ of the depth calculated for the maximum draught. It is being adopted that the canalized rivers, which are constructed almost as artificial watercourses intended for navigation, shall guarantee safe navigation with maximum draught at low navigable water level corresponding to the water level of $95 \%$ duration. 


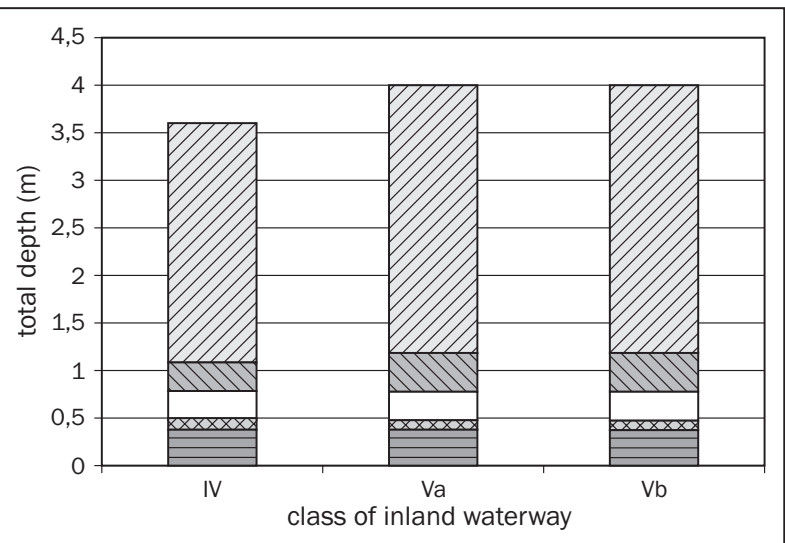

$\square 7$ Draught $(\mathrm{m}) \quad \square$ Absolute reserve $(\mathrm{m})$ Longitudinal trim $(\mathrm{m}) \quad \Longrightarrow$ Speed sink $(\mathrm{m})$

Figure 4 - Depth of navigable channel in natural and trained rivers

\subsection{Detailed parameters for waterway classification on the Sava River}

The parameters which were analyzed in the previous chapters and other parameters were used as base for enactment of decisions [14], [15] and [16]. These decisions have defined legal scope for the classification of the Sava river waterway by the International Sava River Basin Commission.

\section{THE SAVA RIVER NAVIGABILITY ANALYSIS}

The Croatian section of the Sava from Račinovci to Sisak was especially analysed. As per AGN Agreement, the mentioned section of the Sava under the designation E-80-12 was listed in the European waterway of class IV. However, in its present state the following sections do not comply with the declared class: 203+300 (Račinovci)-305+700 (SI. Šamac) class IV, 305+700 (SI. Šamac)-330+200 (Oprisavci) class III, 330+200 (Oprisavci)-363+200 (SI. Brod-grad) class IV, 363+200 (SI. Brod-grad)-594+000 (Sisak) class III. Section 583+000 (Sisak)-651+000 (Rugvica) has not been declared an international waterway and has class II [13] (Chainage in Sava kilometre marks). Based on the conducted analysis of the morphological characteristics of the Sava there are eight critical waterway sections (Figure 5) from Račinovci to Sisak [17], needing waterworks in order to comply with the criteria of class IV. Within the scope of work [19] the remaining part of the Sava waterway from Belgrade to Račinovci has been analyzed.

In the decision [20] section from Sisak to Brčko is declared as class IV and from Brčko to Belgrade as class Va. The decision to apply class IV from Brčko to Sisak is mainly because of the morphological reasons as well as from state and ecological reasons. "No-cutoff-meanders" principle was adopted.

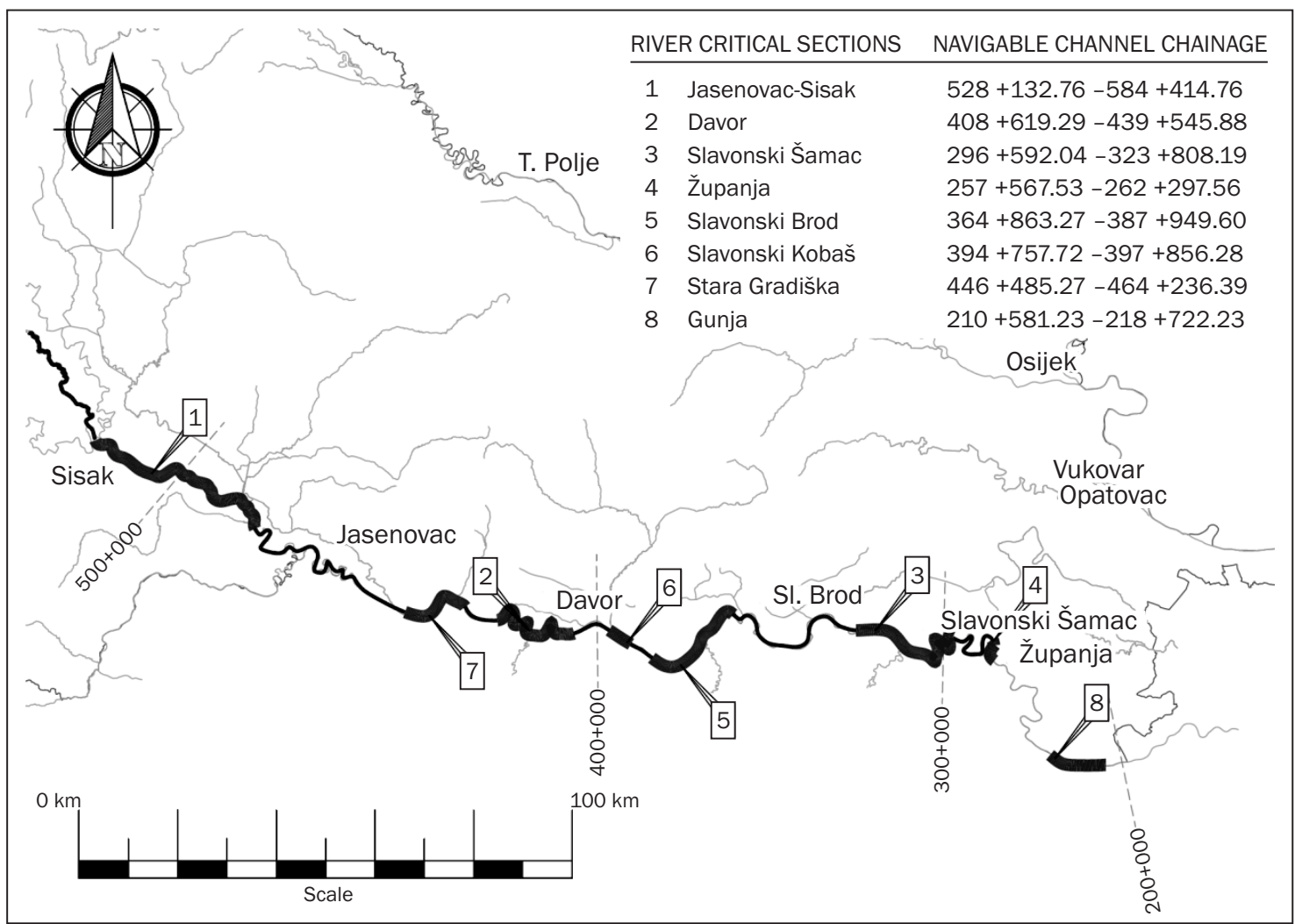

Figure 5 - Critical sections of the Sava waterway in Croatia requiring considerable water works in order to comply with class IV criteria from Sisak to Brčko and class Va criteria from Brčko to Račinovci (Chainage of the Sava navigable canal) [17] 
M. Pršić, D. Carević, D. Brčić: Determining Inland Waterway Parameters with Application to the Sava River

Table 2 - Estimated financial resources for achieving Class IV and Va for the Sava waterway from Belgrade to Sisak [16]

\begin{tabular}{|c|c|c|}
\hline & Total for SCC Class IV & Total for SCC Class Va \\
\hline & [Euro] & [Euro] \\
\hline Dredging and training works & $34,929,200$ & $39,108,600$ \\
\hline Enviromental costs & $1,005,000$ & $1,340,000$ \\
\hline Bridge replacements & $8,880,000$ & $8,880,000$ \\
\hline River bend improvements (total) & $11,360,000$ & $11,360,000$ \\
\hline Markings and sunken vessels & $1,835,000$ & $1,835,000$ \\
\hline RIS & $5,790,000$ & $5,790,000$ \\
\hline Net cost & $63,799,200$ & $68,313,600$ \\
\hline Including contingencies (+10\%) & $70,179,120$ & $75,144,960$ \\
\hline Total project costs $(+15 \%)$ & $80,705,988$ & $86,416,704$ \\
\hline
\end{tabular}

The financial resources needed in order to achieve class IV - for the Sava waterway (from Belgrade to Sisak) have been estimated based on the consideration as referred to in [19], as follows in Table 2. It was not predicted to use the cut-offs in the meanders, instead, one way navigation in the bends and points for waiting are assumed.

In order to achieve class IV for the Sava waterway upstream from Rugvica the unit price per kilometre should be almost 9 times higher than downstream from Rugvica [19].

\section{INSTEAD OF A CONCLUSION}

Parameters IV, Va and Vb of the international waterway classes have been developed for the purpose of the Sava waterway classification and training. Those parameters have been obtained by comparative analysis of the inland waterway parameters, made on the basis of international classifications, available theoretical presumptions, and available experimental tests. Based on the thus set standards, the analysis of morphological characteristics of the Sava from Račinovci to Sisak was performed, in order to reach conclusions on the scope of the required waterworks for the purpose of achieving the declared international class IV and $\mathrm{Va}$ of the Sava waterway.

Class IV waterway with the navigable channel of $72 \times 3.6[\mathrm{~m}]$ and the minimal radius of $360[\mathrm{~m}]$ may be executed through river training works at $31 \%$ of its length. The navigable clearance does not comply at $29 \%$ of the length, and the minimum radius $2 \%$ of the length. It is thus being recommended that the direct water works' measures be implemented in order to achieve complete correction of the navigable channels and that meander cut-offs should be avoided at too low radius due to state and ecological reasons. The navigation in those places shall be one way for the standard push convoy, while for smaller towed convoys and smaller self-propelled ships it may be twoway. Waterway Va was also analyzed for the purpose of comparison. The navigable channel being $89 \times 4.0[\mathrm{~m}]$ (including somewhat reduced towing) does not comply at $40 \%$, while the minimum radius of 360 [m] does not comply at $2 \%$ of the length.

Given the decision [20] where class IV from Sisak to Brčko and class Va from Brčko to Belgrade were provided, class $\mathrm{Vb}$ which is considered in this paper is hardly expected in foreseeable future.

The financial load of the required works for the purpose of achieving the conditions for the international class IV of the Sava River navigability from Račinci to Sisak has been estimated at about $80,000,000$ euro. The realization is to be sought in interstate agreements in about 5 to 10 years' time.

Dr. sc. MARKO PRŠIĆ

E-mail:mprsic@grad.hr

Dr. SC. DALIBOR CAREVIĆ

E-mail: car@grad.hr

Sveučilište u Zagrebu, Građevinski fakultet

Kačićeva 26, 10000 Zagreb, Hrvatska

Dr. sc. DAVOR BRČIĆ

E-mail: davor.brcic@fpz.hr

Sveučilište u Zagrebu, Fakultet prometnih znanosti

Vukelićeva 4, 10000 Zagreb, Hrvatska

\section{SAŽETAK}

\section{ODREĐIVANJE PARAMETARA RIJEČNIH PLOVNIH PUTOVA S PRIMJENOM NA RIJEKU SAVU}

U članku je predstavljena definicija parametara riječnih plovnih putova, s naglaskom na međunarodnu IV, Va i Vb klasu riječnog plovnog puta relevantnih za Savu. Definicija parametara obavljena je komparativnom analizom temeljem međunarodnih klasifikacija unutarnjih plovnih putova, raspoloživih teorijskih postavki, te raspoloživih rezultata istraživanja na fizikalnom modelu. Problematika kanalskih parametara nije razmatrana.

Filozofija važeće UN/ECE klasifikacije iz 1992. sastoji se u definiranju samo mjerodavnih plovnih sastava i plovnih vodostaja. Prema njima se tada za svaki pojedini plovni put, temeljem morfologije plovnog korita, kroz morfološkotehničko-ekonomsku analizu određuju parametri plovnog 
puta. Takvim iterativnim postupkom stvorena je detaljna standardizacija parametara savskog plovnog puta za međunarodne klase IV, Va i Vb. To je bio temelj za tekuću analizu plovnosti rijeke Save, u cilju dobivanja orijentacije o potrebnim hidrograđevnim radovima i financijskoj dimenziji potrebnih radova za kratkoročno i dugoročno razdoblje.

\section{KLUUČNE RIJEČI}

unutarnji plovni put, Sava, klasa plovnog puta, standardizacija, morfologija riječnog korita.

\section{LITERATURE}

[1] European Agreement on Main Inland Waterways of International Importance (AGN), United Nations, Economic Commission for Europe, Inland Transport Committee, Geneva, 19 January1996. (RH subscripts AGN in the year 1997 and puts AGN in full application in the year 1999)

[2] UN/ECE: United Nations, Economic and Social Council, Economic Commission for Europe, Inland Transport Committee: Classification of European Inland Waterways, Resolution No. 30, TRANS/SC.3/131, p. 183, Geneva, November 1992

[3] UN/ECE: United Nations / Economic Commission for Europe: Classification of European Inland Waterways, Geneva 1960

[4] Commission du Danube: Recommendations Relatives a L'etablissement des Gabarits du Chenal, des Ouvrages Hydrotechniques et Autres sur le Danube, Budapest 1975

[5] PIANC: Factors Involved in Standardising the Dimensions of Class Vb Inland Waterways (Canals), International Navigation Association, Report of Working Group $\mathrm{n}^{\circ} 20$ of the Permanent Technical Committee I, PIANC Supplement to Bulletin $n^{\circ} 101,1999$

[6] Wiegleb, K.: Wassertechnik, Band 4, Verlag für Bauwesen $\mathrm{GmbH}$, Berlin, 1997

[7] Graewe, H.: Beitrag zur Frage der Bemessung von Fahrwasser-Verbreiterungen in Kanal - und Flusskrümmungen, Die Bautechnick, H.1, Berlin 1971

[8] Kuhn, R.: Bemessungsgrundlagen für die Fahrwassertiefen des Europakanal Rhein - Main - Donau, Schiff und Hafen, 25 Jhg.H1, Seehafen Verlag Hamburg 1973
[9] Der Bundesminister für Verkehr: Richtlinien für Regelabmessungen des Nord - Westdeutschen Kanalnetzes, Der Bundesminister für Verkehr, Abteilung Binnenschiffahrt und WasserstraßenWasser und Schiffahrtdirektion, Hanover, 1990

[10] Commission du Danube: Recommandations Relatives a L'etablissement des Gabarits du Chenal, des Ouvrages Hydrotechniques et Autres sur le Danube, Budapest 1975

[11] Partenscky, H.-W.: Binnenverkehrswasserbau: Schleusenanlagen, Springer Verlag, Berlin, Heidelberg, New York, Tokyo, 1986

[12] Pršić, M., Tadejević, Z.: Riječni plovni putevi, Fakultet građevinskih znanosti Zagreb, 1987

[13] Pravilnik o razvrstavanju i otvaranju plovnih putova na unutarnjim vodama, NN 9/2006

[14] International Sava River Basin Commission: DECIDION-26/06, International Sava River Basin Commission, Ref, No: 1R-2-D-06-20/1-2, November 15, 2006

[15] International Sava River Basin Commission: DECIDION-19/08, International Sava River Basin Commission, Ref, No: 1S-9-D-08-5/1-3, April 8, 2008

[16] International Sava River Basin Commission: DECIDION-13/09, International Sava River Basin Commission, Ref, No: 1S-12-0-09-31/2-2, May 7, 2009

[17] Uređenje savskog plovnog puta i određivanje regulacijske linije Save od Račinovaca do Siska, Preliminary design, Faculty of Civil Engineering Zagreb, 2005

[18] Stručna podloga za petogodišnji plana razvitka plovnih putova i luka unutarnjih voda, Study, Faculty of Civil Engineering Zagreb, 2006

[19] International Sava River Basin Commission: Feasibility and Project Documentation for the Rehabilitation and Development of Transport and Navigation on the Sava River Waterway, Final report, Executive summary, 25 September 2008

[20] International Sava River Basin Commission: DECIDION-21/09, International Sava River Basin Commission, Ref. No: WD-09-6/1-3, Zagreb, June 29, 2009

[21] Ivaković, Č., Rogić, K., Orlić Protega, A.: Traffic on the Croatian Inland Waterways in the Context of the European Programme Naiades, PROMET Traffic\&Transportation, Vol. 20, No. 6, 2008, pp. 383393 